DOI: $10.17516 / 1997-1370-0881$

УДК 792.8+82-293

\title{
The Interplay of Ballet and Literature: Translation Issues
}

\author{
Sergey S. Sokovikov* \\ Chelyabinsk State Institute of Culture \\ Chelyabinsk, Russian Federation
}

Received 10.10.2021, received in revised form 10.12.2021, accepted 18.01.2022

\begin{abstract}
The history of addressing of ballet art to literature has lasted for more than one century. However this cooperation increasingly causes discrepant appraisements from both specialists and viewership. They even offer opinions about unnatural character of alliance of ballet and literature as completely heterogeneous phenomena. Literature sources in their softer variant refer to be only a distant primary push for completely self consistent and autonomous choreographer's creativity. Such affirmations seem to be not enough convincing. Bearing in mind inevitability of organic relations between various phenomena, belonging to one and the same cultural sphere, while interacting, each one reproduces definite features of the other. This is all the more characteristic in the situation of intersemiotic translation of the text content into a language common to a phenomenon of another indicative nature. In this case basis of adequate translation is built from common significant patterns characteristic of the both texts. For literature and ballet such patterns are visually entertaining aspects of a work, embodying narrative, conceptual and emotional aspects of the content. They are internally enclosed into the literature text, they are perceived by a choreographer, and they form basis for the creative conception. Specification of a scenic image is an aspect of a complex of actual sociocultural contexts of the historic epoch, in which the act of transferring of literature into a ballet action takes place.
\end{abstract}

Keywords: ballet art, literature, intersemiotic translation, visually entertaining patterns, literature implication, visual metaphor, narration and spectacle, socio-cultural context.

Research area: theory and history of culture.

Citation: Sokovikov, S.S. (2022).The interplay of ballet and literature: translation issues. J. Sib. Fed. Univ. Humanit. soc. sci., 15(1), 115-123. DOI: 10.17516/1997-1370-0881

(C) Siberian Federal University. All rights reserved

* Corresponding author E-mail address: akseniya.krupkina@mail.ru ORCID: 0000-0002-2151-2684 


\title{
Взаимодействие балета и литературы: проблемы перевода
}

\author{
С.С. Соковиков \\ Челябинский государственный институт культуры \\ Российская Федерачия, Челябинск
}

\begin{abstract}
Аннотация. Балетное искусство многократно обращалось к сюжетам художественной литературы как источнику хореографического творчества. Однако это взаимодействие все больше вызывает разноречивые оценки со стороны специалистов и зрительской аудитории. Подобный союз литературы и балета видится в том числе противоестественным в силу их принципиальной разнородности. С такой точки зрения литературные источники представляются в лучшем случае неким первичным толчком для совершенно самостоятельного и автономного творчества хореографа. Вместе с тем анализ показывает, что подобные утверждения принципиально неточны. В них недооценивается органическая связь различных явлений, принадлежащих одной сфере культуры, когда при их взаимодействии каждое неизбежно воспроизводит определенные черты другого. Это особенно характерно для ситуации интерсемиотического перевода содержания текста на язык, присущий явлению иной знаковой природы. При этом одним из условий адекватного перевода служат общие выразительные паттерны, присущие обоим текстам. В ситуации взаимодействия литературы и балета такими паттернами являются визуально-зрелищные аспекты произведения, воплощающие сюжетные, смысловые и эмоциональные стороны содержания. Они изначально присущи литературному тексту, воспринимаются хореографом и влияют на его творческое решение. Конкретное воплощение сценического образа уточняется совокупностью актуальных социокультурных контекстов исторического времени, в котором происходит акт перевода литературы в балетное действие.
\end{abstract}

Ключевые слова: балетное искусство, литература, интерсемиотический перевод, визуально-зрелищные паттерны, литературный подтекст, визуальная метафора, повествование и зрелище, социокультурный контекст.

Научная специальность: 24.00.01 - теория и история культуры

\section{Introduction}

The reviewed subject is of interest primarily in the wider context of visualization of the modern cultural space. Visually significant artifacts are becoming more and more influential. This takes special significance due to a certain crisis of the book reading culture. In this respect visualization of literature writings is considered as one of the factors, supporting interest to literature texts. Simultaneously this situation contributes to saturation of the visually-spectacular sphere with informative artifacts, which use literature texts of various genres, different stylistics and degree of trans- lation. The second aspect, having fundamental significance, contains complex processes of interaction of various phenomena in the sphere of artistic culture. Transformation of the original texts at their translation into the language of different arts is retained as a cause of discussions about a degree of adequateness to the sources, discrepancy in estimations given by specialists and the audience of art. In this context one of the most significant is the problem of interaction between ballet art and literature. Thus analysis of theoretical argumentation of various positions, along with reference to modern artistic practices are considered to be 
expedient to define characteristic foundations for a possibility of substantial translation of a literature text into a ballet action. It is also significant to explore whether such transformation can be considered as translation in the course of interaction between the original text and the succeeding spectacular performance, or if the choreographer's work arises as a completely autonomous artifact, maintaining solely nominal connection with the literature source.

\section{Theoretical framework}

As the theoretical basis of this problem analysis we consider a conceptual idea of organic connection between the phenomena, being the aspects of the same cultural sphere, but embodied in various semiotic systems. Such connection determines possibility of recoding of one phenomenon in the language of the other one. At such an intersemiotic translation a newly arising text preserves a definite semiotic connection with the original source, but, in view of linguistic difference, it also gains additional senses. Adequacy of translation is defined by presence of the common contextual patterns, inherent in the both texts. Contentrichness and effectiveness of the derived text is specified with the total of actual socio-cultural contexts, operating at the process of intersemiotic translation.

\section{Statement of the problem}

The basic problem of analysis of interaction between ballet and literature is contradiction between absolutization of the role of ballet-master at resorting to a literature source, representation of the complete selfdependence of the ballet text, and inevitability of projection of the literature work substantial aspects in the scenic act. It gives rise to necessity for search of factors and contextual conditions, providing possibilities of translation of a literature text into the language of scenic forms, and also retaining semantic connection between the original source and the derived choreographic text.

\section{Methods}

We consider that the methods, adequate to the examined problem, are the comparative text analysis of conceptual positions in the aspects of ballet dramatizing literature works, fact analysis of the modern artistic practices in the aspects of the presented range of problems, functional analysis of visually entertaining images as integrating foundations of writers and choreographers' creativity.

\section{Discussion}

The history of addressing of ballet art to literature has lasted for more than one century. This process is becoming a more and more frequent practice during the $20^{\text {th }}$ and $21^{\text {st }}$ centuries. Choreographers are attracted with both literature classics and the tests of the newest epoch, textbook works, having «transparent» subjects, and the most difficult artifacts with «lurking» conceptual implications, not easy for reading. The choreographic stylistics itself is amazing for diversity of creative idioms of ballet-masters and for courage of plastic concepts.

However interactions of literature and ballet are not as simple as it may appear. Accordingly Poel Karp supposes that between these fields there are unnatural relations, because «ballet, being not satisfied with something penetrating into its flesh, starves for relying on direct literature source» (Karp, 1980: 203). The art critic insists on importance of the ballet text itself and on its independence from «any props, remaining outside the performance notwithstanding if it is a voluminous literature work or a tiny theatre playbill» (Karp, 1980: 206). $\mathrm{He}$ is being repeated by Lugovaya, considering self-sufficiency of the ballet text: «attempts to join ballet with literature $\langle\ldots\rangle$ are very rare to be effective, because the language of ballet and the language of literature are two completely different languages, having diverse tools, diverse tasks and diverse manners of communicating with reader/spectacular» (Lugovaya, 2019: 366). Following this logic line the author considers that the basis of independence of ballet performance is connected not with the quality of its literature source, and not with the accuracy of its choreographic reading, but with some «integral unity» as a result of "translation possessing artistic adequacy» (Lugovaya, 2019: 370). But what may this «adequate trans- 
lation» be, apart from exact choreographic reading of a literature work?

However, this view contains its own difficulties. According to Poel Karp, «reserves of adequacy are hidden in the structuralinformative basis of ballet», in what connection «its creator may be only a human being, possessing specific ballet way of thinking, ballet perception of reality. $\langle\ldots\rangle$ the profession of a writer itself doesn't have any special suppositions to it, and it is extraneous for the most writers» (Karp, 1980: 206).

And as ballet-master here and there has no ability of plot-making» [Ibidem], there is emerging vicious circle, meaning vision of lack of prospects in a union between ballet and literature. This is even more convincing if one considers that such a union is «just a stage in the history of this kind of art» (Lugovaya, 2019: 370 ), accentuating this phenomenon as temporary, transient. Even in dramatic writings, which seem to assume, as one would think, having also entirely expressed plastic basis, one can see «load of the word», contradicting the original language of ballet, which «reduces verbal expression to a minimum» (Karp, 1980: 128). It gives birth to categorical judgments, saying, for example, that dramaturgy of «Hamlet», apart from not containing specific ballet dramaturgy, is to a large extents anti-ballet and can't «be joined to ballet implementation» (Karp, 1980: 206). This example is especially illustrative in that aspect that such a judgment is completely apart from reality. N. S. Shabalina gives a list of choreographers' attempts to work with «Hamlet» (beginning from 1788), including 43 cases, and 38 performances from this list belong to the second half of the $20^{\text {th }}-$ the beginning of the $21^{\text {st }}$ centuries (Shabalina, 2018: 99-102). For example, a famous balletmaster John Neumeier addressed the Shakespeare's text for four times (in 1976, 1985, 1997, 2013) (Shabalina, 2018: 88-90). This highly professional choreographer has one very precise statement: «Hamlet is traditionally considered to be an anti-ballet play. But such plays don't exist. There are either plays, unlocked with the ballet key, or ones which are not still unlocked with it» (Quotation from: Shabalina, 2018: 88). Moreover, increase of number of bal- let addressing to literature, being joined with distinct widening of thematic diversity of literature sources gives evidence of not «impermanence» of relations between choreography and belles-letters, but of apparent development of this tendency.

At that we should mention that differences in understanding interaction between ballet and literature are quite stable. It is worthy of note that in case of negative literature-based estimation of a ballet performance the leading principle for criticism is the same - it is fundamental diversity of languages of choreography and belles-lettres - for example: «We became witnesses of an effort to retell the great tragedy by means of the language of music and dancing, and this attempt became homiletic for its ineffectiveness» (critic M. Tarakanov about «Hamlet» performed by K.M. Sergeev) (Quotation from: Shabalina, 2018: 84). Moreover, it repeatedly generates a thesis about fundamental «non-transferability» of a considerable part of literature into choreographic forms. According to this, Poel Karp, for example, judgmentally announces: «Ballet is the direct antipode of Chekhov's drama» (Karp, 1980: 110). Highly-eloquent response to this statement can be given by means of a far from complete list of choreographic interpretations of Chekhov's texts: «The lady with the dog» (ballet performance by M. Plisetskaya with the music by R. Schedrina), «Anna on the neck» (ballet performance by V. Vasiliev with the music by V. Gavrilin), «Ward number six» (ballet performance by Radu Pokletaru with the music by Arvo Pyart), «Black monk» (ballet performance by I. Reinholde with the music by S. Prokofiev and D. Shostakovich), «Seagull», «Black monk» and «Ward number six» (ballets «Nina - materialization of immolation» and «Nameless poison» - Black monk» by Jo Kanamori), «Hunting drama» (ballet performance by A. Fadeechev with the music by P. Chaikovskiy and E. Dogy), "Cherry tree garden» (ballets «S. V.» by P. Adamchikov; «Endless graden» by Nacho Duato with the music by A. Schnitke; "Whispering of flowers» by Lin Hwai-min with the music by J.S. Bach), «Three sisters» (ballet performance «Winter dreams» K. McMillan with the music 
by P.I. Chaikovskiy), «Seagull» (ballet performances by Jh. Neumeier and B. Eifman) (Krasnova, 2016: 174-175). Attention should be paid not only to astonishing diversity of music material, used by stage managers, but also to that fact that each of them is a creator with unique handwriting and individual, original and creative vision of ballet stylistics. Such contest gives full legitimacy to the conclusion, done by I. A. Krasnova, and saying that «Chekhov's Prose and dramaturgy contains image systems of a high degree of «choreography-like» (Krasnova, 2016: 174).

However, it gives birth of an inquiry, far from idle, which leads to recalling critics' judgments about «unnatural character' of community of literature and ballet art: are choreographic 'five-finger exercises» more attempts to modify their literature motives than to express them? Doubts of such a kind are characteristic: literature basis of ballet performances often undergoes so radical changes that «kinship» with the primary source looks very distant. Let's take into consideration a statement, made by a ballet-master A. V. Elizarov: «Starting to work with a literature primary source, one should proceed from the conviction that any primary source is endlessly distant from the nature of choreographic theatre (Elizarov, 2013). This is an affirmation, as one would think, of categorical diversity of literature and ballet texts.

It is not surprising that the most whimsy shows appear at the stage. Thus at the performance «Evgeniy Onegin» by Boris Eifman the scene is carried over to "wild 90s» of the $20^{\text {th }}$ century with all the attributes characteristic for that epoch. The subject is enriched with the circumstances of the August putsch of 1991, the characters are also defiantly modernized: Lenskiy has the look of a bard with the inseparable guitar, the provincial smart society resemble knackers, Tatiana's husband is presented as a «demonic» figure of a generalbusinessman with bandit-like habits. Tatiana's dreams are filled with open eroticism, the duel turns into a knife-fight, and peasant dancing looks as a village discotheque. In the final scent Onegin implants himself on the blinded general-bandit's knife... It should be added that
B. Eifman combined in his performance classical music by P. I. Chaikovskiy and the melodies by a rock-musician A. Sitkovetskiy ("Autograph»). Is this a sacrilege? A stage manager's arbitrariness? But E. N. Tarasenko testifies: «In retelling it sounds almost anecdotic, but at seeing the performance any stage manager's whim looks surprisingly convincing (Tarasenko, 2018: 93). And we should accentuate that such a liberal dealing with the literature primary basis is absolutely not an attribute of today. This also took place earlier, including Pushkin's classics. According to M. A. Vedernikova's saying, «the ballet world remade in its own way, and goes on remaking Pushkin's writings, sometimes beyond recognition. For example, in «Goldfish» by A. Saint-Leon (1867) the audience saw not the old man and woman, but a young pair, or there is another example: Sh. Didelot in «Caucasian captive» (1823) adds a character, whom A.S. Pushkin hasn't created - the captive's bride. In a version of «Queen of spades» by Roland Petit (1978) Hermann fell in love with the old countess, and she loved him back. Lisa became a supporting character» (Vedernikova, 2019: 40).

But there are also other situations. For example, in a staging of "Carmen» by a Swedish choreographer Mats Ek the principle heroine corresponds with the character, written in Prosper Merimee's novella even in a greater degree than the character of the Georges Bizet's opera. But we should have in mind that in the case of intersemiotic translation, which is transposition of one text into another sign impressing system, the content of the primary source is being objectively transformed. Analysis of art practices and materials of scientific researches shows that this translation into the language of choreography works even for the most difficult texts (Krasnova, 2018: 245). The question is raised about a degree at which a choreographic work preserves its semantic connection with its literature source. The general algorithm of such a translation is clear: «at reading a literature work a choreographer «translator» gets an idea, which later gives birth to a new plastic reading the literary text» (Krasnova, 2018: 247). But what gives birth to an idea which makes it possible to transmit the 
semantic aspects of the literature text in an artifact of completely different indicative nature.

As a rule, analysis of this problem proceeds from statement of fundamental difference of the languages of literature and choreography. Much less attention is paid to the matter that connects them and even becomes common for them. Agreeing that «ballet always has possibility to leave for non-narrative play of forms and sensations» (Lugovaya, 2019: 373 ), it is necessary to note that it is addressing literature that makes it possible to refrain from coming into a «non-narrative play», retaining other content aspects, connecting choreography and the art of word together with the effect of the «pure» ballet language. And such practices nowadays don't prove that fact that ballet «tries to speak with not its own voice». The history of choreography has passed the stage, when it «didn't have enough its own artistic means for expressing the aspects of a plot by the language of dancing - and dance gave place to melodeclamation, buffoonery, dramatic theatre (Belayeva, 2015: 131). Development of the ballet language, besides its own choreographic meaning, gave possibility to address literature texts even not on the level of plastic «illustration», but as an independent version of their imaginative semantic content in its own sign expressive system.

Interpretation of this kind includes a widest diapason of variations: from performances, following the narrative outline of a literature text and maintaining the authenticity of historic details to performances of modernist type, radically transforming the dramaturgy of the primary source and actively using the techniques of bricolage, rhizomality, intertextuality and so on (Shabalina, 2018: 82). More of this, researchers refer the original joining of choreography with belles-letters to the general tendencies of development of the ballet art of the $21^{\text {st }}$ century in general (Tarasenko, 2018: 93). Let's note that the analogical approaches to the imaginative determination at intersemiotic translations are used also in other kinds of artistic culture - theatre, cinema, graphic arts, music.

Thus we can surely suppose that stability of this art-esthetic tendency together with the widest range of its manifestations is defined by objective basements of various levels. It stands to reason that interaction between ballet and literature forms a complex phenomenon, which depends on many factors. It is expedient to mark those of them which are more closely connected with the peculiarities of transformation of a belles-letters text into plastic images. One of them, as we consider, can be seen in the cultural-anthropological basements of the art phenomenon itself. As we know, the roots of artistic activity are in the primary myth-ritual complex. Myth is a narration for which ritual is a form of its actual presentation, that is of its entertaining implementation. Development of artistic activity led to detachment and original individualization of different kinds of arts. In spite of this, mythological aspects went on to project into the artistic sphere, in this respect both literature and ballet are mythological in their own way. Together with this, as it is stated by K.A. Vorotintseva and E. V. Malikov who analyze correlation between myth and narration in ballet, in the process of «degradation of mythologized worldview and profanation of socialized routine, myth experience is changed for its auditing and / or reading; that is, mystery is changed for text» (Vorotintseva, 2018: 63).

In such a manner, mythological aspects more often get narrative literature forms, which are less actual in their visual form. But dancing preserves such visually-spectacular actuality, including the force of its genetic connection with its mystery roots. Moreover, this circumstance also defines the nature of ballet spectacle itself: «there are mystery roots in dancing, and its ancient generic capacity presents itself implicitly in ballet» (Vorotintseva, 2018: 63). In this case misteriality means not mystery of the action, but its image-symbolic staginess, embodying certain narration in its open and vivid visual form. Thereby ballet gains ability to turn a story (narration) into a demonstration (show), that is, figuratively speaking, is a step to come back from reading to mystery».

Together with that such a common approach is not enough to give understanding of what exactly in this translation gives a choreographer an impulse for a strict plastic decision. At a contrastive analysis of literature texts 
and their ballet implementations researchers exaggerate special role of undertones, contained in primary sources (Krasnova, 2018: 245; Krasnova, 2016: 175). The literary tissue of the literature text has implicitly present hidden senses, containing the inner essence, being represented by interaction of personages and, this being specifically important, forming the specter of the emotional and sensual sinuosity of the plot. Something, not represented in words, but being caught in the shades of intonations, mimics, gesture and other situational details, makes it possible to transmit all that acts in the characters' souls (Krasnova, 2016: 175). Besides, counterpoint and ambiguousness of all the totality of the undertones makes it possible to construct his own author's version of the visuallt-spectacular reading of the literature text more than to reconstruct the author's ideas.

It is quite clear that such a procedure has the character of an adapted translation, at which some transformations of the plot collisions, peculiarities of the cultural environment, historical peculiarities, represented in the original source, are not only inevitable, but in some instances are just necessary. At this the most significant role belongs to emotional efficiency, which composes a specific peculiarity of the ballet art. That information, which is hidden and just implicated, is revealed in a choreographic variant, and is embodied into a really perceived action. I. A. Krasnova and M. V. Lanina emphasize quite correctly: «in many cases dance is capable to express the most subtle shades of feelings, which can't be expressed by means of speech, and they are to be read only in the subtext of a literature text» (Krasnova, 2018: 245). Let's give special attention to that fact that source of the sensual and emotional structure of a ballet work is just the subject of the literature text.

«But what is the physically expressed «repository» of this content? As we suppose, attention should be paid to the following: a peculiar connecting bridge, providing intersemiotic translation of literature images into choreographic ones, can be arranged by visually-spectacular aspects, being contained in the nature of the both phenomena. It is especially significant in the modern cultural space, in which the most significant role is given to entertaining images. Visual perception gains total character, at which "reader frequently gives place to spectator» (Krasnova, 2016: 173). Inner visuality of the literature text, which is, as one would think, a well-known circumstance, gains a specifically important significance for its projection onto the ballet stage. Just at the stage of the writer's intention visually-spectacular images and feelings, connected with them, make substantial influence on the subject ideas and the style of the work, being represented in its text. And these images don't compose an «external cover» of the plot, they convey not only ideas and feelings of the personages, but also carry more total existential meanings. According to the pertinent remark by T.A. Boborikina, «literature with all its concentration on the word sphere, recourses to visual image, which, as a formula, is capable to condense meanings and to replace the whole pages of descriptions» (Boborikina, 2019: 6). Perceiving this content, choreographer also catches spectacularly-plastic aspects, using this basis for forming their visual equivalents in the language of ballet, or, using T.I. Boborikina's remark, visual metaphors (Boborikina, 2019: 6). Search of such a metaphor is the task for a ballet-master, addressing a literature text.

But it shouldn't be interpreted just as a «free flight of imagination», randomness of fantasy, limited only by a totality of choreographic expressive means. Decision of plastic interpretation of the images is born with considering interpenetration of the contexts, containing, besides the other, visually-spectacular experience of the actors, included into the total situation. This is the experience, belonging to the author of a literature text and that culture which he is a representative of. Further, this is the visual context of the literature work as a whole. Visual experience and peculiarities of the choreographer's plastic vision specifically interact with the above-mentioned spectacular aspects. Finally, one of the most powerful influences on developing a plastic metaphor is produced by the context of the spectator audience's visual culture. It is impossible to reach a high level of the decision accuracy without considering this factor. It is the choreographer 
who actualizes the function of combining all these contexts and adopting the uniquely creative decision which considers all of them. It is notable that E. N. Tarasenko, analyzing John Neumeier's productions of literature works, marks: «stage manager is in time to think for the performer, the ballet personage and for the spectacular $\langle\ldots>$ considering various levels of perception (narrative, poetic, symbolic, philosophic) depending on the intellectual potential of the audience (Tarasenko, 2018: 89).

\section{Conclusion}

Consequently we can resume: development of literature and ballet art generates more and more frequent cases of choreographers' addressing to literature works. This translation of narrative texts into visually-spectacular form is determined from one side by reinforcement of visualization of the cultural space, from the other side by compensatory desire of the modern civilization to recover some archaic motives, in the given case - mysterial-mythological ones. Analysis of the experience and modern practices proves not only reinforcement of interaction between ballet and literature, but also significant enrichment of the creative decisions spectrum, including addressing the most complex texts. Competence and effectiveness of these decisions are significantly defined by visuallyspectacular aspects, specifically inherent for literature and ballet, providing possibility for an adequate intersemiotic translation. Dominance of the choreographic stage manager on the modern ballet stage finally provides originality of the creative decision of a definite performance. At the same time such a decision arises with considering the spectrum of visually-spectacular contexts, producing various conceptual experience of writers, viewing audience, participants of the staging process, and also the conditions of the visual culture of the past epochs (in retro projections) and the modernity.

\section{References}

Belyaeva, E. (2015). Kak balet osvaival bol'shuyu literaturu [How ballet assimilated great literature]. In Peterburgskij teatral'nyj zhurnal [Petersburg theatrical journal]. 3(81), 130-134.

Boborykina, T. A. (2019). V poiske vizual'noj metafory: Dostoevskij na yazyke baleta i kino [In search of the visual metaphor: Dostoevskiy in the language of theatre and cinema]. In Vestnik Tomskogo gosudarstvennogo universiteta. Kul'turologiya i iskusstvovedenie [Herald of Tomsk State University. Culturology and art criticism]. 34, 5-18.

Vedernikova, M. A. (2019). Pushkinistika v otechestvennom baletovedenii: istoriograficheskij obzor [Search of Pushkin in the native history of ballet: Historiographic survey]. In Kul'tura i obrazovanie [Culture and education]. 3(34), 39-45.

Vorotynceva, K. A., Malikov, E. V. (2018). Mif i povestvovanie v balete [Myth and narration in ballet]. In Vestnik Tomskogo gosudarstvennogo universiteta. Kul'turologiya i iskusstvovedenie [Herald of Tomsk State University. Culturology and art criticism]. 29, 63-73.

Elizarov, A. V. (2013). K probleme libretto v sovremennoj horeograficheskoj postanovke, Allbest.ru. [Due to the issue of libretto in the modern choreographic staging, Allbest.ru.]. Available at: https://otherreferats.allbest.ru/culture/00287270 0.html (accessed 30 June 2020)

Karp, P. M. (1980). Balet i drama [Ballet and drama]. Leningrad, Iskusstvo, 246 p.

Krasnova, I. A. (2018). «Lost in translation?»: popytka perevoda romana I. S. Turgeneva «Nakanune» na yazyk horeografii [«Lost in translation»: an attempt to translate the novel by I. S. Turgenev «On the eve» into the language of choreography]. In Perevod. YAzyk. Kul'tura: Materialy IX mezhdunarodnojnauchnoprakticheskoj konferencii [Translation. Language. Culture: Materials of the $9^{\text {th }}$ international practical conference]. Sankt-Petersburg, 244-249.

Krasnova, I. A., Lanina, M. V. (2016). Horeograficheskoe prochtenie skrytyh smyslov v proizvedeniyah A.P. Chekhova [Choreographic reading of the hidden senses in the works by A. P. Chekhov]. In Slavyanskij sbornik: Materialy XII Vserossijskih Slavyanskih CHtenij «Duhovnye cennosti i nravstvennyj opyt russkoj civilizacii v kontekste tret'ego tysyacheletiya» [Slavonic digest: Materials of the 12 $2^{\text {th }}$ All-Russian Slavonic 
readings "Moral values and ethic experience of the Russian civilization in the context of the third millennium]. Orel, 172-180.

Lugovaya, E. K. (2019). Balet i literatura: trudnosti perevoda [Ballet and literature: Problems of translation]. In Prepodavanie yazykov i kul'tur v paradigme gumanitarnogo obrazovaniya [Teaching languages and cultures in the paradigm of humanitarian education]. 366-374.

Tarasenko, E. N. (2018). Tendencii razvitiya baletnogo iskusstva v XXI veke [Tendencies of development of ballet art in the $21^{\text {st }}$ centure]. In Uchenye zapiski Komsomol'skogo-na Amure gosudarstvennogo tekhnicheskogo universiteta [Scholar notes of Komsomolsk-on-Amur State Technical Iniversity]. 1(33), 87-93.

SHabalina, N. S. (2018). «Gamlet» na baletnoj scene vtoroj poloviny XX - nachala XXI vekov [«Hamlet» on the ballet stage of the second half of the $20^{\text {th }}$ - the beginning of the $21^{\text {st }}$ centuries]. In Vestnik Akademii russkogo baleta im. A. YA. Vaganovoj [Herald of Academy of Russian ballet named for A. Ya. Vaganova]. 5 (58), 78-102. 